\title{
PEMBELAJARAN BIOETIKA SEBAGAI PENGAWAL PERKEMBANGAN BIOLOGI MODERN DAN PENYELAMATAN LINGKUNGAN HIDUP
}

\author{
Eko Budi Minarno \\ Fakultas Sains \& Teknologi UIN Maliki Malang \\ Email; Eko.Budi@g.mail.com
}

\begin{abstract}
Abstrak
Perkembangan biologi modern telah menghasilkan keuntungan yang luar biasa bagi kesejahteraan hidup manusia, namun di sisi lain juga menimbulkan dampak negatif. Oleh karena itu, diperlukan bioetika untuk mengawal perkembangan biologi modern agar memiliki komitmen terhadap kemaslahatan alam. Pembelajaran bioetika perlu dikembangkan dengan orientasi utama pada pengembangan kemampuan berpikir kritis peserta didik. Metode yang dapat dilakukan adalah melalui pengembangan kemampuan pengambilan keputusan model ABCDE. Selain untuk mengawal perkembangan biologi modern, bioetika juga penting untuk membelajarkan etika lingkungan yang bersumber pada etika biosentrisme dan etika ekosentrisme, sebab etika antroposentrisme cenderung mengantarkan perilaku manusia menjadi eksploitatif terhadap alam.

Kata Kunci: Bioetika, Biologi Modern, Lingkungan
\end{abstract}

\section{Pendahuluan}

Sejak akhir abad ke-20, biologi telah mengalami perkembangan yang pesat. Fokus kajian biologi telah mengalami perubahan yang signifikan, bukan hanya terbatas pada tingkat organisme atau sel, melainkan lebih dalam lagi ke tingkat molekuler, sehingga dikenal dengan biologi molekuler. Perkembangan biologi molekuler diawali dengan penemuan struktur kimia DNA oleh Watson dan Crick pada tahun 1953 (Jenie, 1997). Produk-produk perkembangan biologi molekuler ini selanjutnya merupakan basis untuk perkembangan biologi modern.

Perkembangan biologi modern yang pesat, sejak lama telah diprediksi akan menimbulkan juga problem-problem etika. Perkembangan IPTEK sebagai suatu prestasi, tidak jarang juga memunculkan masalah baru yakni masalah yang berkaitan dengan etika (Bertens, 1990). Nor (1999) juga mengemukakan bahwa kloning, rekombinasi DNA, transfer embrio (ET) dan fertilisasi in vitro (IVF) selain memungkinkan "mengontrol" proses kehidupan, juga membawa pertanggungjawaban baru terhadap masyarakat, sehingga perlu kehati-hatian dalam mengaplikasikannya. Kehati-hatian yang dimaksud perlu diwujudkan antara lain dalam bentuk kajian aspek etika pada saat penerapan teknologi (Jenie, 1997; Santosa, 2000; Djati, 2003). Sejalan dengan hal ini, Johansen \& Harris (2000) dan Hasan (2001) juga mengemukakan bahwa hasil penelitian yang tidak mempertimbangkan aspek moral, etika, sosial,dan budaya, akan menimbulkan banyak permasalahan di masyarakat. Demikian pula Sudarminta (1992) mengemukakan perlunya suatu dialog antara etika dan ilmu pengetahuan untuk sarana pertimbangan etik yakni apakah ilmu pengetahuan tersebut baik bagi manusia menurut totalitasnya sebagai manusia dan tidak hanya menurut kebutuhan tertentu saja. Oleh karena itu, aspek etika yang berkaitan dengan aplikasi biologi modern perlu mendapatkan perhatian yang serius.

Perkembangan biologi modern yang pesat bukan berarti harus dihambat, namun yang benar adalah 'dikawal' agar tetap berjalan pada koridor kemaslahatan umat dan alam semesta. Hal ini sesuai dengan tugas manusia sebagai khalifah di bumi, sebagaimana dikemukakan dalam AlQur' an Surat Yunus ayat 14:

"Kemudian kami jadikan kamu sekalian khalifahkhalifah di muka bumi sesudah mereka, supaya kami memperhatikan bagaimana kamu berbuat".

Tugas khalifah adalah sebagai pengelola yang berarti bertanggungjawab terhadap kemaslahatan. Dengan demikian ilmuwan biologi, tidak sepatutnya mengabaikan tanggung jawab terhadap kemanusiaan dan alam semesta ini. Oleh karena itu, diperlukan suatu ramburambu yang bernama bioetika untuk mengontrol riset biologi modern Bioetika dan Keputusan Etik

Etika yang berkaitan dengan masalah biologi dikenal dengan nama bioetika (Shannon, 1995). Bioetika atau bioethics atau etika biologi didefinisikan oleh Samuel Gorovitz (dalam Shannon, 1995) sebagai "penyelidikan kritis tentang dimensi-dimensi moral dari pengambilan 
keputusan dalam konteks yang berkaitan dengan biologi". Jadi bioetika menyelidiki dimensi etik dari masalah-masalah teknologi, ilmu kedokteran, dan biologi yang terkait dengan penerapannya dalam kehidupan (Shannon, 1995). Definisi lain tentang bioetika ialah the study of ethical issues and decision making associated with the use of living organisms (Macer, 2001).

Jenie (1997) mengemukakan bahwa bioetika berperan antara lain sebagai pengaman bagi riset bioteknologi. Sedangkan Djati (2003), menegaskan bahwa bioetika tidak untuk mencegah perkembangan ilmu pengetahuan dan teknologi antara lain bioteknologi, tetapi menyadarkan bahwa ilmu pengetahuan dan teknologi mempunyai batas-batas dan tanggung jawab terhadap manusia dan kemanusiaan.

Di sisi lain, perkembangan penelitian biologi modern seperti genom manusia, teknologi reproduksi, kloning, transgenik semakin berkembang, yang memerlukan kebijaksanaan sosial dan sikap individu. Hal inilah yang menyebabkan perlunya membelajarkan bioetika, sebab melalui pembelajaran ini akan dapat mengembangkan kemampuan berpikir dan bertindak yang sesuai dengan etika dan moral.

Sebagai lembaga pendidikan, sekolah memiliki tanggung jawab untuk meningkatkan kemampuan berpikir dalam menetapkan suatu keputusan yang sesuai dengan etika dan moral. Oleh karena itu, lembaga pendidikan mempunyai beban dan tanggung jawab untuk melaksanakan pembelajaran yang terkait dengan etika (bioetika) serta membantu siswa mengembangkan cara-cara dalam membuat keputusan etik (Kormondy dalam Margono, 2003).

Perwujudan tanggung jawab ilmu pengetahuan dan teknologi terhadap manusia dan alam semesta dapat dilakukan antara lain melalui pengembangan pembelajaran biologi modern yang terintegrasi dengan isu-isu yang berkaitan dengan etika. Fullick \& Mary Ratcliffe (1996) dan Johansen \& Harris (2000) menegaskan, melalui integrasi sains dengan etika diharapkan dapat memberikan kontribusi terhadap kemampuan peserta didik dalam pengambilan keputusan yang berkaitan dengan problem etik.

\section{Bioetika dan Agama}

Apakah pembelajaran bioetika masih diperlukan, sedang di sisi lain mahasiswa atau peserta didik telah mendapat kuliah agama? Terkait pertanyaan ini, dapat dikemukakan bahwa pembelajaran bioetika tetap diperlukan.
Secara umum dapat dikatakan bahwa bioetika (sebagai cabang etika) tidak akan dapat menggantikan agama, tidak bertentangan dengan agama, bahkan diperlukan oleh agama (Suseno, 1987). Dikemukakan pula oleh Suseno (1987), bahwa ada masalah dalam bidang moral agama yang tidak dapat dipecahkan tanpa penggunaan metode-metode etika. Masalah tersebut adalah masalah interpretasi terhadap perintah atau hukum yang termuat dalam wahyu, dan yang kedua ialah bagaimana masalah-masalah moral yang baru seperti bayi tabung, aborsi, kloning, bank sperma, eutanasia, dan sebagainya yang tidak langsung dibahas dalam wahyu, dapat dipecahkan sesuai dengan semangat agama tersebut.

Bagaimana dengan agama Islam, apakah bioetika diperlukan? Oleh karena bioetika adalah cabang dari etika, maka pada pembahasan ini banyak digunakan istilah etika. Sutiah (2003) mengemukakan bahwa etika, moral, dan akhlaq mempunyai hubungan yang erat satu sama lain. Etika dan moral sebagai kajian tentang baik dan buruk suatu perbuatan, ditentukan berdasarkan akal pikiran dan kebiasaan masyarakat, sedangkan akhlaq berdasarkan wahyu. Namun, etika, moral dan akhlaq tetap saling membutuhkan, sebab dalam pelaksanaannya, norma akhlaq di dalam al-Qur' an dan as-Sunnah masih bersifat tekstual ("belum siap pakai"). Untuk melaksanakan ketentuan akhlaq yang terdapat di dalam al-Qur'an dan al-Hadist, dibutuhkan penalaran dan ijtihad oleh umat. Untuk itu, keberadaan etika dan moral sangat dibutuhkan dalam rangka menjabarkan dan mengoperasionalisasikan ketentuan-ketentuan akhlaq yang terdapat di dalam al-Qur'an dan alHadist. Bertens (2005) mengatakan, etika tidak berbicara untuk suatu komunitas homogen, karena etika mengarahkan diri kepada suatu forum umum yang hanya berpegang pada rasio. Melihat uraian ini, maka bioetika sebagai cabang etika diperlukan sebagai wahana penalaran atau ijtihad yang terkait dengan perkembangan biologi dan teknologinya.

Dengan demikian, pembelajaran bioetika tidak ada masalah dengan agama Islam, bahkan dibutuhkan, sebab bioetika menekankan pada pengembangan berpikir untuk menentukan sisi baik buruk atau dimensi etis dari biologi modern dan teknologi yang terkait dengan kehidupan, sedangkan Islam sendiri sangat menekankan pentingnya berpikir. Rasulullah s.a.w memberikan pernyataan tentang peranan akal dalam beragama "Agama itu adalah penggunaan 
akal, tiada agama bagi orang yang tidak berakal, al-Hadits)". Keharusan manusia untuk selalu menggunakan akal dan pikirannya difirmankan Allah dalam Q.S. Al-Ghosyiyah, ayat 17-20:

“ .... maka apakah mereka tidak memperhatikan unta bagaimana ia diciptakan (aspek reproduksi dan fisiologi), dan langit bagaimana ia ditinggikan (aspek fisika), dan gunung bagaimana ia ditegakkan (aspek geologi), dan bumi bagaimana ia dihamparkan (aspek geografi)".

Pentingnya pengembangan kemampuan berpikir ini sangat perlu mendapatkan perhatian. Sebagaimana yang dikemukakan oleh Corebima (1999), bahwa di dalam pembelajaran, penalaran oleh siswa atau mahasiswa harus dikelola dengan sebaik-baiknya (secara langsung, terencana dan sengaja). Kegagalan pembelajaran selama ini diakibatkan tidak terkelolanya aspek berpikir atau penalaran siswa dengan baik. Di sisi lain, kemampuan berpikir terutama berpikir kritis, merupakan bagian yang fundamental bagi kematangan manusia dalam menghadapi era globalisasi ini (Liliasari, 2000). Pengabaian terhadap kemampuan berpikir kritis ini, akan menyebabkan ketidakmampuan dalam menghadapi persaingan yang ketat di abad pengetahuan ini.

\section{Teori Etika dalam Pengambilan Keputusan terhadap Dilema Bioetika}

Perkembangan ilmu pengetahuan antara lain biologi, telah menimbulkan dilema-dilema serius dan mendalam, yang menantang sistem nilai kita maupun kebudayaan yang didasarkan atas nilai-nilai tersebut (Shannon, 1995). Di dalam pengambilan pengambilan keputusan etik yang sering harus dilakukan dalam kaitannya dengan bioetika, ada 2 teori dasar atau teori etika atau metode yaitu Konsekuensialisme, dan Deontologi (Shannon, 1995; Johansen \& Harris, 2000).

Pada konsekuensialisme, baik buruknya suatu perbuatan tidak ditetapkan atas dasar prinsip-prinsip, tetapi dengan menyelidiki konsekuensi perbuatan. Oleh karena memiliki nama "konsekuen-sialisme". Metode ini mencoba untuk meramalkan apa yang akan terjadi, jika kita berkelakuan dengan berbagai cara yang berbeda, dan membandingkan hasilnya satu dengan yang lain. Apa yang bersifat moral atau moralitas suatu perbuatan ditentukan melalui suatu proses evaluatif. Dengan konsekuensialisme, seseorang tidak cukup melakukan yang baik, melainkan mestinya tahu perbuatan paling baik di antara semua perbuatan baik yang mungkin atau menyediakan kebaikan yang terbesar untuk sebanyak-banyaknya orang (Mackinnon dalam Johansen \& Harris, 2000).

Istilah "deontologi" berasal dari kata Yunani deon yang berarti "tugas/kewajiban/keharusan/prinsip" (Shannon, 1995; Johansen \& Harris, 2000). Etika deontologis adalah metode pengambilan keputusan yang mulai dengan bertanya "Apa yang harus saya lakukan?" atau "Apa yang menjadi kewajiban saya?" Menurut pandangan ini, jalan etik tepat yang harus ditempuh seseorang adalah mengikuti prinsip-prinsipnya entah ke manapun ia terbawa. Dalam hal ini mereka tidak peduli akan konsekuensikonsekuensinya. Begitu keharusan atau kewajiban ditetapkan, maka jelaslah sudah perbuatan apa yang harus dilakukan. Begitu mengenal aturan dan mengetahui kewajiban, sudah menjadi jelas apa yang etik dan apa yang tidak etik. Problem terbesar adalah deontologi tidak peka terhadap konsekuensi-konsekuensi perbuatan.

Bagaimana dengan Islam? Islam sangat menekankan pada kemampuan berpikir, keputusan etik dilakukan melalui pertimbangan yang sangat cermat antara kemaslahatan dan kemudhorotan sesuatu hal. Konsekuensialisme lebih sesuai dalam Islam untuk mencari solusi dalam menghadapi kasus dilema bioetika (kasus yang menimbulkan perdebatan terkait penerapan biologi atau teknologi berbasis biologi). Pembelajaran bioetika dapat dilakukan dalam bentuk menentukan keputusan etik melalui kajian antara resiko dan manfaat, keputusan yang mendatangkan kemaslahatan paling banyak dengan paling sedikit kemudhorotannya.

Rasulullah s.a.w telah mengajarkan tentang pengembangan pola pikir yakni "Agama itu adalah penggunaan akal, tiada agama bagi orang yang tidak berakal". Berdasarkan hal ini, maka yang harus mendapat perhatian dalam pembelajaran bioetika adalah pengambilan keputusan etik dengan tidak mengajarkan atau memberi contoh keputusan etik apa yang harus diambil, melainkan menekankan pada bagaimana cara atau proses untuk pengambilan keputusan etik.

\section{Model Pengambilan Keputusan terhadap Dilema Bioetika}


Uraian berikut adalah model $\mathrm{ABCDE}$ (Johansen \& Harris, 2000) yang dapat digunakan dalam pengambilan keputusan etik.

\section{Model ABCDE}

Pada model ini, mahasiswa dapat diminta untuk memikirkan argumentasi yang bertentangan, keuntungan dan kelebihan, serta perolehan keputusan terakhir berdasarkan pada kejujuran pribadi. Langkah-langkah dalam model ini adalah sebagai berikut:

A. Argumentasi. Meminta dengan tegas kepada mahasiswa untuk memberikan argumentasi sederhana, pendek/singkat sebelum mengkaji sisi lain dari argumentasinya.

B. Both Sides. Meyakinkan bahwa suatu argumentasi mempunyai dua atau lebih sisi yang dapat didekati dari perspektif konsekuensi. Mengingatkan para mahasiswa untuk membuat suatu keputusan dengan konsekuensi. Adalah penting untuk mendorong mahasiswa untuk melihat bahwa ada sisi lain.

C. Costs and Benefits. Menggunakan informasi yang telah mereka kembangkan terkait dengan keuntungan dan kerugian masingmasing argumentasi.

D. Decision. Penggunaan diskusi terbuka dan debat, agar mahasiswa dapat menjangkau suatu keputusan atau kesimpulan. Tidak berarti seluruh kelas perlu setuju. Bagaimanapun, ini adalah hal yang sangat berharga untuk memperoleh keputusan akhir, sebab hal inipun mencerminkan proses di dalam masyarakat yang lebih luas. Kemungkinan keputusan disetujui oleh mayoritas pemilih atau oleh konsensus, atau tidak semua orang setuju, namun hal yang utama adalah proses pengambilan keputusan telah diikuti dan mahasiswa menjadi bagian dari proses pengambilan keputusan tersebut.

E. Evaluate. Semua argumentasi, keuntungan dan kerugiannya, manfaatnya dievaluasi.

Model ini mempunyai keuntungan antara lain mudah untuk menjelaskan dan menawarkan suatu proses pengambilan keputusan secara langsung. Di samping itu, model ini juga menyediakan forum untuk menjelaskan nilai-nilai yang dimiliki dan memahami pandangan orang lain. Melalui proses ini, mahasiswa akan menemukan informasi baru, menganalisis pandangan orang lain, mempertentangkan dengan yang mereka miliki, dan mengembangkan argumentasi. Keputusan sebagai bagian dari proses ini memberikan peluang pada mahasiswa untuk belajar menerima secara sosial dan secara moral. Pada langkah evaluasi, dapat diketahui konsekuensi dari keputusan yang diambil. Penggunaan model ini tidak akan membuat semua orang senang atau setuju, tetapi akan menawarkan kepada mahasiswa suatu kesempatan untuk menguji proses pengambilan keputusan etik dengan menyelidiki hal-hal di luar nilai-nilai yang mereka miliki.

\section{Penerapan Pembelajaran Bioetika untuk Pendidikan Lingkungan}

Paradigma manusia terhadap lingkungan perlu diubah agar sikap dan perilaku manusia lebih arif dan bijaksana dalam memaknai alam. Krisis lingkungan global bersumber pada kesalahan fundamental-filosofis dalam pemahaman atau cara pandang mengenai dirinya, alam, dan tempat manusia dalam keseluruhan ekosistem. Kesalahan cara pandang ini bersumber dari etika antroposentrisme yang memandang manusia sebagai alam semesta. Manusia dianggap berada di luar dan terpisah dengan alam. Alam sekedar alat pemuas manusia. Cara pandang seperti ini melahirkan sikap dan perilaku kapitalistik yang eksploitatif tanpa kepedulian sama sekali terhadap alam. Krisis lingkungan hanya dapat diatasi dengan melakukan perubahan cara pandang dan perilaku manusia terhadap alam dari etika antroposentrisme ke etika biosentrisme dan ekosentrisme. Etika antroposentrisme cenderung mangantarkan perilaku manusia yang eksploitatif terhadap alam.

Rasulullah misalnya dalam hadits riwayat Bukhari bersabda:" Tidaklah seorang muslim yang menanam suatu tanaman, lalu dimakan oleh burung, manusia ataupun binatang, kecuali hal itu (dinilai sebagai) sedekah baginya”. Nabi SAW juga bersabda “ Jikalau kamu dipastikan mati esok pagi, sementara di tanganmu terdapat benih korma, maka tanamlah!" Bahkan ketika Rasulullah SAW mem-briefing pasukan jihad, beliau senantiasa berpesan "...jangan kalian bunuh perempuan, anak-anak, laki-laki yang renta, jangan kalian rusak tempat-tempat ibadah, dan jangan kalian tebang pohon-pohon". Dalam kondisi darurat perang saja dilarang menebang pohon, justru dalam keadaan damai, puluhan juta hektar hutan luluh lantak.

Paradigma manusia terhadap lingkungan dapat diubah melalui pembelajaran bioetika atau 
etika lingkungan. Mahasiswa dibelajarkan untuk mengambil keputusan terkait lingkungan, karena dalam hidup adalah pengambilan keputusan. Etika lingkungan hidup menuntut agar etika dan moralitas tersebut diberlakukan juga bagi komunitas biotis atau komunitas ekologis. Etika lingkungan harus juga dipahami sebagai refleksi kritis atas norma-norma dan prinsip atau nilai moral yang selama ini dikenal dalam komunitas manusia untuk diterapkan secara lebih luas dalam komunitas biotis dan komunitas ekologis. Di samping itu, dalam perspektif etika lingkungan ini manusia harus memperlakukan alam tidak semata-mata dalam kaitannya dengan kepentingan dan kebaikan manusia.

Di samping topik-topik tentang produk perkembangan biologi modern, pembelajaran bioetika sangat mungkin untuk diisi dengan topik-topik lingkungan sebagaimana berikut ini, sekaligus menunjukkan peran bioetika, misalnya:

- Dalam 20 tahun ini tidak akan ada lagi hutan tropis dataran rendah dan tinggi di Sumatera, Kalimantan dan Sulawesi, jika kecepatan penggundulan hutan di Indonesia secepat seperti sekarang ini.

- Tanah akan berubah menjadi perkebunan kelapa sawit, karet, kopi, kakao, dan lain-lain.

- Beberapa tanaman berbunga bersama dengan sejumlah serangga, jamur, bakteri, dan lainlain akan menghilang selamanya; lingkungan hidup baru mungkin tidak akan mendukung tumbuh berkembangnya makhluk-makhluk hidup ini.

- Ada kemungkinan adanya tumbuhan yang mempunyai nilai komersial yang belum diungkap atau dikenali antara lain gaharu, gambir, nilam, dan yang lain.

- Banyak tumbuhan yang menghilang dengan cepat; berkejar-kejaran dengan waktu.

\section{Penutup}

Bioetika (etika biologi) sangat diperlukan sebagai pengawal riset biologi modern dan juga penyelamatan lingkungan. Pembelajaran bioetika tidak dilakukan dengan mendoktrin suatu keputusan apa yang harus diambil oleh peserta didik. Islam membelajarkan pengembangan kemampuan berpikir kritis melalui analisis maslahat-mudlorot dalam pengambilan keputusan etik menghadapi munculnya dilema bioetika sebagai akibat perkembangan biologi modern dan tindakan terhadap lingkungan. Bioetika harus dibelajarkan melalui berpikir dan memprediksi konsekuensi dari tindakan yang dilakukan, dalam hal ini juga memprediksi kemaslahatan dan kemudlorotan yang akan muncul.

Mendiskusikan keputusan melalui berbagai pendapat baik yang pro maupun kontra adalah hal yang sangat berharga untuk mengembangkan wawasan dan kemampuan berpikir kritis mahasiswa. Proses memperoleh keputusan dari suatu fenomena biologi modern perlu dibelajarkan kepada mahasiswa dengan berlandaskan filosofi konstruktivistik (bahwa pengetahuan harus dikonstruksi oleh mahasiswa dan bukan didoktrinkan), agar mahasiswa sebagai ilmuwan biologi dapat mempertimbangkan tindakan-tindakan yang akan dilakukan sebagaimana pengembangan pola berpikir yang dikemukakan Rasulullah s.a.w.

\section{Daftar Rujukan}

Bertens, K. 1990. Bioetika Refleksi Atas Masalah Etika Biomedis. Jakarta: Gramedia.

Bertens, K. 2005. Bioetika dan Globalisasinya

(http://www.kompas.co.id/kompacetak/0504/06/Bentara/1661650.htm diakses 28 Nopember 2005.

Corebima, D. 1999. Proses dan Hasil Pembelajaran MIPA di SD, SLTP dan SMU: Perkembangan Penalaran Siswa Tidak Dikelola Secara Terencana (Studi Kasus di Malang, Yogyakarta, dan Bandung). Makalah disajikan dalam Seminar on Quality Improvement of Mathematics and Science Education in Indonesia, Bandung, 11 Agustus.

Djati, M.S. 2003. Diskursus Teknologi Embryonic Stem Cells dan Kloning dari Dimensi Bioetika dan Relegiositas (Kajian Filosofis dari Pengalaman Empirik). Jurnal Universitas Paramadina, 3(1): 102-123.

Fullick, P. \& Mary, R. 1996. Teaching Ethical Aspects of Science. Hampshire: Hobbs The Printers Limited.

Hasan, A.M. 2001. Pentingnya Pengajaran Etika Biologi (Bioetika) dalam Menghadapi Abad Pengetahuan. Jurnal Pendidikan Nilai Universitas Negeri Malang. 8 (1).

Jenie, U.A. 1997. Perkembangan Bioteknologi dan Masalah-Masalah Bioetika yang Muncul. Makalah disampaikan dalam Temu Ilmiah Regional Hasil Penelitian Biologi dan Pendidikan Biologi/IPA di IKIP Surabaya, Surabaya: 4 Januari 1997. 
Johansen, C.K. and Harris, D.E. 2000. Teaching the Ethics of Biology. The American Biology Teacher, 62 (5) : 352-358.

Liliasari. 2001. Model Pembelajaran IPA untuk Meningkatkan Keterampilan Berpikir Tingkat Tinggi Calon Guru sebagai Kecenderungan Baru pada Era Globalisasi. Jurnal Pengajaran MIPA, 2 (1): 55-65.

Macer, D.R.J. 2001. Bioethics for the People by the People. Chrischurch, N.Z., Eubios Ethics Institute.

Margono, D. 2003. Analisis Kemampuan Berpikir Moral terhadap Tes Dilema Bioetika pada Siswa SMU Jember. Teknobel, 4 (1) : 9-14.

Nor, S. N. M. 1999. New Reproductive Biotechnology, Values and Society. Eubios Journal of Asian and International Bioethics (EJAIB) 9 , 166-9 : 1-7.

Santosa, H. 2000. Landasan Etis bagi Perkembangan Teknologi. Yogyakarta: Tiara Wacana.

Shannon, T.A. 1995. Pengantar Bioetika. Terjemahan oleh K. Bertens. Jakarta : Gramedia Pustaka Utama.

Suseno, F.M. 1987. Etika Dasar. Yogyakarta: Kanisius.

Sutiah. 2003. Metode Pembelajaran Aqidah Akhlak dengan Pendekatan Perkembangan Kognitif. El-Hikmah, 1 (1): 25-49. 